\title{
Concanavalin A-Induced Decrease in Cell Surface Charge and its Modification by Sulfhydryl Blocking Agents
}

\author{
Kiyohide Kojima, Chikako Sato*, Kimiko Nishizawa* and \\ Satoru Shimizu** \\ Department of Oncological Pathology, Nara Medical University, Kashihara 634, \\ and Laboratories of ${ }^{*}$ Experimental Radiology and ${ }^{* *}$ Ultrastructure Research, \\ Aichi Cancer Center Research Institute, Nagoya 464, Japan
}

\begin{abstract}
The electric surface charge of mouse melanoma B16-C2W cells treated with various concentrations of Con A was determined by cell electrophoresis. At Con A concentrations higher than $5 \mu \mathrm{g} / \mathrm{ml}$, the cellular electrophoretic mobility decreased significantly at 10 minutes incubation, but this effect was reversed by $\alpha$-methyl-D-mannoside. At these higher Con A concentrations, more than $30 \%$ of Con A receptors were bound with lecitn. Pretreatment of cells with sulfhydryl blocking agents, $10^{-5} \mathrm{M}$ p-chloromercuribenzoic acid or $10^{-5} \mathrm{M}$ N-ethylmaleimide, completely prevented the subsequent Con A-induced mobility reduction without changing the amount of Con A-binding to the cell surface. Similar effects were found with pretreatment with protein linkage agents, such as $2 \%$ glutaraldehyde and $10^{-6} \mathrm{M}$ fluorescein mercuric acetate. The removal of chondroitin sulfate with the specific enzyme resulted in a $30 \%$ decrease in electrophoretic mobility of intact cells but produced no change in Con A-treated cells. These results suggest that Con A treatment may induce an alteration in chondroitin sulfate distributions at the cell surface and that sulfhydryl residues of membrane proteins may play an important role in this surface alteration.
\end{abstract}

Many cancer cells are aggregated by concanavalin A (Con A) (8) or wheat germ agglutinin (1), while their ancestral normal cells do not show this effect. This reactivity difference to lectins between neoplastic and normal cells is probably related to the rearrangement of lectin receptors on the cell surface $(9,11-13,20)$. Electron microscopic studies have demonstrated in most neoplastic cells that Con A receptors form cluster easily in bindings with Con $A$, resulting in cell aggregation $(11,12)$. Other cell surface alterations induced by Con A, however, are not yet fully elucidated.

To clarify details on cell surface changes induced by Con $A$, we studied alterations of electric surface charge in mouse melanoma cells after treatment with Con $A$ by cell electrophoresis coupled with chemical modifications of the cell surface.

\section{MATERIALS AND METHODS}

The mouse melanoma cell line B16-C2W (2) was used. The cells were maintained in vitro in Ham's F12 medium supplemented by $10 \%$ fetal calf serum as described previously (15).

Crystallized Con A in saturated sodium chloride (carbohydrate free) was obtained from Miles Yeda, Illinois. The lectin had no any proteolytic enyzme or glycosidase activity in our 
screening tests. Con A was labeled with $\mathrm{Na}^{125} \mathrm{I}$ (carrier-free) by slight modification (17) of the Sonoda method (21). The newly prepared iodinated Con A was immediately used. Following treatment with Con A at different concentrations, the cells were washed twice with Hank's balanced salt solution, and then mechanically striped off from the culture dish with a rubber policeman.

Cell electrophoresis was performed in $66 \mathrm{mM}$ phosphate-buffered saline supplemented with $0.25 \mathrm{M}$ sorbitol ( $\mathrm{pH}, 7.3$; ionic strength, 0.167 ), as previously reported (10). Measurements of cellular electrophoretic mobility were made at $25 \pm 0.5^{\circ} \mathrm{C}$ with a cytopherometer (Zeiss).

For chemical modifications of the cell surface, sulfhydryl-blocking agents, such as $10^{-5} \mathrm{M}$ p-chloromercuribenzoic acid (PCMB) and $10^{-5} \mathrm{M}$ N-ethylmaleimide (NEM), and protein linkage agents, such as $2 \%$ glutaraldehyde and $10^{-6} \mathrm{M}$ fluorescein mercuric acetate (FMA) in phosphate buffered saline, were used.

For enzymatic modification, neuraminidase from Vibrio cholerae (General Biochemicals, Chagrin Falls, Ohio), chondroitinase-ABC from Proteus vulgaris (Seikagaku Kogyo, Tokyo), and hyaluronidase from Streptomyces (Seikagaku Kogyo, Tokyo) were used at a concentration of 20 units $/ \mathrm{ml}$ in Hank's solution at $\mathrm{pH} 7.0,1 \mathrm{unit} / \mathrm{ml}$ in Veronal-buffered saline supplemented with $0.1 \%$ egg albumin at $\mathrm{pH} 8.0$ and 10 turbidity-reducing units/ml in Veronalbuffered saline with $0.1 \%$ egg albumin at $\mathrm{pH} 6.0$, respectively. Neuraminidase showed no chondroitinase or hyaluronidase activities, and the chondroitinase and hyaluronidase showed no neuraminidase activity. Streptomyces hyaluronidase (14) digested only hyaluronic acid, and the chondroitinase- $\mathrm{ABC}$ (23) was specific for the respective chondroitin sulfates.

\section{RESULTS}

Con A-induced alteration in the electric surface charge of cells. Fig. 1 shows changes in electrophoretic mobility of melanoma cells treated with Con A at different concentrations. Cell mobility was significantly decreased at concentrations higher than $5 \mu \mathrm{g} / \mathrm{ml}$, while no significant change in mobility was observed at concentrations

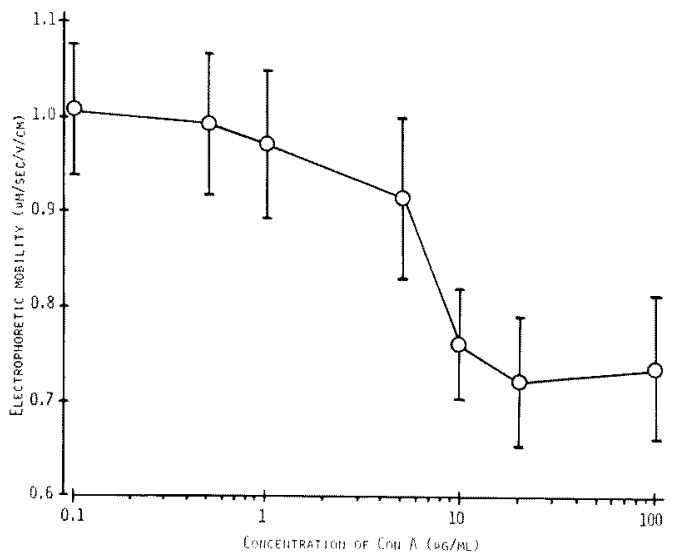

Fig. 1. Changes in electrophoretic mobility of $\mathrm{C} 2 \mathrm{~W}$ cells after treatment with Con $\mathrm{A}$ at different concentrations. Cell electrophoretic mobility was measured after treatment with Con A at $37^{\circ} \mathrm{C}$ for $30 \mathrm{~min}$. Each point indicates the mean mobility value of 40 cells. The vertical lines represent standard deviations. 
lower than $1 \mu \mathrm{g} / \mathrm{ml}$. The decrease in negative surface charge by the lectin was induced within $10 \mathrm{~min}$ of incubation and reverted by addition of $\alpha$-methyl-D-mannoside (Fig. $2)$.

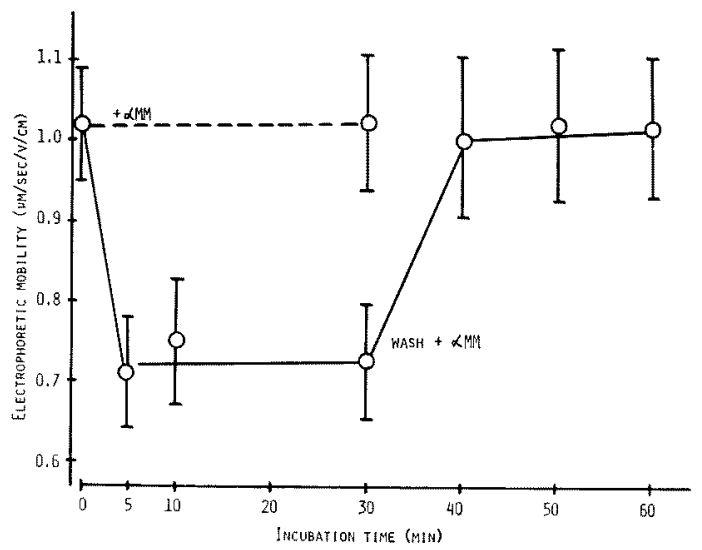

Fig. 2. Time course changes in electrophoretic mobility of $\mathrm{C} 2 \mathrm{~W}$ cells after Con A treatment and their reversibility after treatment with $\alpha$-methyl-D-mannoside. The cells were treated with Con A at $20 \mu \mathrm{g} / \mathrm{ml}$ in phosphate-buffered saline at $37^{\circ} \mathrm{C}$ and the electrophoretic mobility of more than 40 cells was measured at the indicated time intervals. After Con A treatment for $30 \mathrm{~min}$, the cells were washed, and the reversibility of mobility was observed by addition of $0.1 \mathrm{~N} \alpha$-methyl-D-mannoside. The vertical lines represent standard deviations. Dotted line indicates cell mobility changes by combined treatment with Con $\mathrm{A}$ and $\alpha$-methyl-D-mannoside. $\alpha \mathrm{MM}, \alpha$-methyl-D-mannoside.

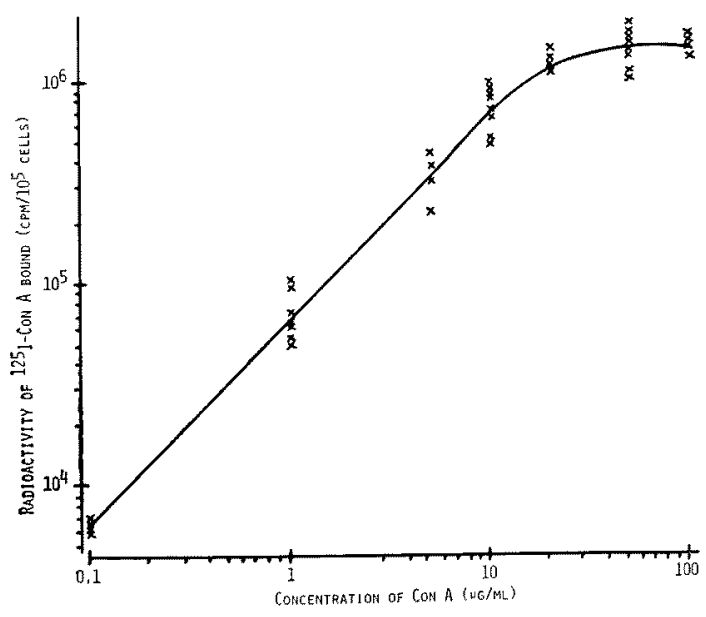

Fig. 3. Correlation between amount of Con $A$ bound to cell surface and concentration of Con $A$ used. The cells were treated with ${ }^{125} \mathrm{I}-\mathrm{Con} \mathrm{A}$ at $37^{\circ} \mathrm{C}$ for $30 \mathrm{~min}$, and the radioactivity bound on the cell surface was counted in a liquid scintillation counter. 
The amount of Con A bound on the cell surface increased in direct proportion with the increase in Con A concentration in the media to $20 \mu \mathrm{g} / \mathrm{ml}$ (Fig. 3). This shows that Con A binding sites were saturated at concentrations higher than $20 \mu \mathrm{g} / \mathrm{ml}$. The results suggest that cell surface charge decreased when more than $30 \%$ of Con $\mathrm{A}$ receptors were bound with lectin (Figs. 1 and 3).

TABLE 1. EFFECTS OF ProteIn LINKAGE AND SULFHYDRYl BLOCKING AGENTS ON CON A INDUCED DECREASE OF ELECTROPHORETIC MOBILITY IN B16C2W CELLS

\begin{tabular}{lcc}
\hline \multicolumn{1}{c}{ Treatment } & $\begin{array}{c}\text { Electrophoretic mobility } \\
\left(\mu \mathrm{m} \cdot \mathrm{sec}^{-1} \cdot \mathrm{v}^{-1} \cdot \mathrm{cm}\right)\end{array}$ & $\begin{array}{c}\text { 1251-Con A binding } \\
\text { (cpm/10 cells) }\end{array}$ \\
\hline No treatment & $-1.061 \pm 0.060$ & $2296 \pm 197$ \\
Con A only & $-0.720 \pm 0.071$ & \\
Glutaraldehyde, $3^{\circ} \mathrm{C} 10 \mathrm{~min}$ & $-1.438 \pm 0.122$ & $2346 \pm 341$ \\
Glut $\rightarrow$ Con A & $-1.420 \pm 0.103$ & \\
Con A $\rightarrow$ Glut & $-1.149 \pm 0.104$ & \\
FMA $10^{-6} \mathrm{M}, 10 \mathrm{~min}$ & $-1.057 \pm 0.070$ & $2173 \pm 320$ \\
FMA $10^{-6} \mathrm{M}, 10 \mathrm{~min} \rightarrow$ Con A & $-1.060 \pm 0.074$ & \\
PCMB $10^{-5} \mathrm{M}, 10 \mathrm{~min}$ & $-1.049 \pm 0.069$ & $2270 \pm 274$ \\
PCMB $\rightarrow$ Con A & $-1.051 \pm 0.054$ & \\
NEM $10^{-5} \mathrm{M}, 10 \mathrm{~min}$ & $-1.047 \pm 0.049$ & $2073 \pm 296$ \\
NEM $\rightarrow$ Con A & $-1.054 \pm 0.070$ &
\end{tabular}

All values are shown as $M \pm S D$. Concanavalin $A$ (Con $A$ ) was used at a concentration of $20 \mu \mathrm{g} / \mathrm{ml}$. The cells were incubated at $37^{\circ} \mathrm{C}$ for $30 \mathrm{~min}$. Glut, glutaraldehyde ( $2 \%$ solution); FMA, fluorescein mercuric acetate; PCMB, p-chloromercuribenzoic acid; NEM, N-ethylmaleimide.

Effects of cell surface modification on Con A alteration. Table 1 shows the effects of various chemical modifications on the Con A-induced mobility reduction of the cell surface. When cells were treated with $10^{-5} \mathrm{M}$ PCMB or NEM, sulf hydryl blocking agents, for $10 \mathrm{~min}$ at $37^{\circ} \mathrm{C}$, the Con A-induced mobility reduction was completely prevented without changing the number of Con A-binding sites at the cell surface. Similar results were obtained by pretreatment of cells with protein linkage agents, such as gultaraldehyde, $2 \%$ solution at $3^{\circ} \mathrm{C}$, or FMA, $10^{-6} \mathrm{M}$ at $37^{\circ} \mathrm{C}$, for $10 \mathrm{~min}$. However, when cells were pretreated with Con A at $20 \mu \mathrm{g} / \mathrm{ml}$ at $37^{\circ} \mathrm{C}$ and subsequently treated with glutaraldehyde, a decrease in cellular mobility was observed

TABLE 2. EFFECT OF ENZYMIC TREATMENT ON ELECTROPHORETIC MOBILITY OF B16C2W CELLS (M $\pm \mathrm{SD})$

\begin{tabular}{|c|c|c|c|c|c|c|c|}
\hline \multirow{3}{*}{ Treatment } & & \multicolumn{3}{|c|}{ Intact cells } & \multicolumn{3}{|c|}{ Con A-treated cells } \\
\hline & & \multirow{2}{*}{$\begin{array}{c}\text { Electrophoretic } \\
\text { mobility } \\
\left(\mu \mathrm{m} \cdot \mathrm{sec}^{-1} \cdot \mathrm{v}^{-1} \cdot \mathrm{cm}\right)\end{array}$} & \multicolumn{2}{|c|}{ Difference } & \multirow{2}{*}{$\begin{array}{c}\text { Electrophoretic } \\
\text { mobility } \\
\left(\mu \mathrm{m} \cdot \sec ^{-1} \cdot \mathrm{v}^{-1} \cdot \mathrm{cm}\right)\end{array}$} & \multicolumn{2}{|c|}{ Difference } \\
\hline & & & $\%$ & $\mathrm{P}$ & & $\%$ & $\mathbf{P}$ \\
\hline Neuraminidase & $\begin{array}{l}\text { Control } \\
\text { Experiment }\end{array}$ & $\begin{array}{l}-1.073 \pm 0.094 \\
-0.802 \pm 0.106\end{array}$ & 25.3 & $<0.01$ & & & \\
\hline $\begin{array}{l}\text { Chondroitinase- } \\
\text { ABC } \\
\text { Hyaluronidase }\end{array}$ & $\begin{array}{l}\text { Control } \\
\text { Experiment } \\
\text { Control } \\
\text { Experiment }\end{array}$ & $\begin{array}{l}-1.046 \pm 0.107 \\
-0.711 \pm 0.059 \\
-1.087 \pm 0.097 \\
-1.088 \pm 0.086\end{array}$ & 32.0 & $\begin{array}{l}<0.01 \\
>0.05\end{array}$ & $\begin{array}{l}-0.896 \pm 0.058 \\
-0.941 \pm 0.038\end{array}$ & 5.0 & $>0.05$ \\
\hline
\end{tabular}

Concentrations were: neuraminidase, 20 units/ml of Hank's salt solution at $\mathrm{pH} 7.0$; chondroitinase$\mathrm{ABC}, 1 \mathrm{unit} / \mathrm{ml}$ of $0.05 \mathrm{M}$ acetate-Veronal-buffered saline at $\mathrm{pH} 8.0$; and hyaluronidase, 10 turbidity-reducing units/ml of $0.02 \mathrm{M}$ acetate-Veronal-buffered saline at $\mathrm{pH} 6.0$. The cells were incubated in each enzymic solution at $37^{\circ} \mathrm{C}$ for $30 \mathrm{~min}$. 
as compared with glutaraldehyde treatment alone.

Ionogenic groups of the cell surface. Changes in cell electrophoretic mobility were estimated after treatment with specific enzymes for sialic acid and acid mucopolysaccharides to examine the distribution of ionogenic groups at the cell surface. The results are shown in Table 2 . When intact cells were treated with neuraminidase and chondroitinase- $\mathrm{ABC}$, the electrophoretic mobility was significantly reduced about $25 \%$ and $30 \%$ in neuraminidase and chondroitinase, respectively. On the contrary, when the cells were pretreated with Con A at $20 \mu \mathrm{g} / \mathrm{ml}$ at $37^{\circ} \mathrm{C}$ for $30 \mathrm{~min}$, no further reductions in cell mobility were found by subsequent treatment with chondroitinaseABC.

\section{DISCUSSION}

Reported Con A effects on cell surface include cell agglutination $(1,8,13)$, clustering of agglutinin-binding sites $(9,11-13)$, changes in electrophoresis (22), and resistance to trypsinization (18). The present experiment has also demonstrated that cell electrophoretic mobility is significantly reduced by Con A treatment at concentrations of more than $5 \mu \mathrm{g} / \mathrm{ml}$. The reduction in electrophoretic mobility is a specific surface alteration for Con A binding on the cell surface since the Con A-induced alteration was reverted by addition of $\alpha$-methyl-D-mannoside which removed more than $60 \%$ of Con A bound from the $\mathrm{C} 2 \mathrm{~W}$ cell surface (17). Cell agglutination and resistance to trypsinization were found in $\mathrm{C} 2 \mathrm{~W}$ cells at these concentrations of Con A (18). Furthermore, the result from the binding experiment of labeled Con A indicated that more than $30 \%$ of Con A receptors were bound with lectin at these higher Con A concentrations.

The surface modification with protein linkage agents inhibited the Con A-induced mobility reduction, although cells treated with glutaraldehyde had a higher mobility value than intact cells, suggesting the presence of potential cationogenic groups at the cell surface $(7,10)$. Since cross-linkage of proteins inhibits their lateral movement on the cell surface (19), the Con A-induced reduction in the surface charge seems to be a phenomenon associated with the rearrangement of Con A receptor proteins at the cell surface. The present study has also demonstrated that pretreatment of cells with sulfhydryl-blocking agents inhibits the Con A-induced mobility reduction without changing the number of Con A-binding sites on the cell surface. The detailed mechanism of its inhibitory effect on mobility reduction is unknown from the present results. We previously reported a reduction in cell electrophoretic mobility after X-irradiation and its protection by pretreatment of cells with sulfhydryl blocking agents (15) or small amounts of Con A (17). This seems to imply a configurational change in receptor proteins by binding of Con $A$ and the participation of sulfhydryl residues of membrane components in the configurational change. Thus, the present results may suggest that sulf hydryl residues of membrane components play an important role in the rearrangement of receptor proteins by binding of Con $\mathrm{A}$.

The study of negatively charged sugars on the cell surface has demonstrated the lack of negative charge due to chondroitin sulfates in Con A-treated cells, since chondroitinase- $\mathrm{ABC}$ treatment was not effective in reducing the electrophoretic mobility of Con A-pretreated cells while effective in intact cells. The Con A used had no proteolytic enzyme and glycosidase activities by our tests. Furthermore, it is unlikely 
that the enzyme was not accessible to the cell surface for cell aggregation produced by Con $A$ treatment, because Con $A$ and the subsequent enzyme treatment were performed without stripping off the cells from the culture dish. We have observed in other cultured cells that Con A treatment of cells resulted in the removal of a larger amount of chondroitin sulfates from the cell surface by enzyme digestion without changing the electrophoretic mobility, as compared with intact cells (Kojima and Sato, in preparation). Under the measuring conditions used, the cell electrophoretic method detects charged groups only within $10 \AA$ of the periphery of the cell surface (6). The present results, therefore, suggest the dislocation of chondroitin sulfate from the peripheral zone to the deeper zones of the cell surface by Con A treatment. Similar alterations in cell surface distributions of acid mucopolysaccharides were also reported in lymphoblastic cells treated with phytohemagglutinin (16).

The results thus indicated that Con A treatment of cells produced not only clustering of the lectin-binding sites but also architectural alterations of other membrane components, such as acid mucopolysaccharides on the cell surface, and suggested the possible involvement of sulfhydryl residues in the architectural membrane alteration. Chondroitin sulfate-protein complex is different from the Con A receptor proteins. The mechanism of information transmission from one receptor protein to another protein is quite obscure. The possible involvement of contractile proteins of the membrane was suggested in the mitogenic effects of Con A $(3,5,24)$. It was also shown that phosphorylation of membrane proteins plays an important role in the rearrangement of membrane molecules (4). Further study is required to elucidate the characteristics of the conformational change in glycoproteins and the information transmission mechanism induced by binding of Con $\mathrm{A}$.

Acknowledgment. This work was partially supported by a Grant-in-Aid for Cancer Research from the Ministry of Education, Science and Culture of Japan.

\section{REFERENCES}

1. Burger, M.M. and A.R. Goldberg. Identification of a tumor-specific determinant on neoplastic cell surfaces. Proc. Natl, Acad. Sci. USA 57, 359-366, 1967

2. Claunch, C., A. Oikawa, T.T. Tchen and F. Hu. Advances in biology of skin. Vol. 8, The Pigmentary System. ed. Montagna W. and F. Hu, Pergamon press, Oxford, pp. 479-488, 1967

3. Edelman, G.M., I. Yahara and J.L. Wang. Receptor mobility and receptor-cytoplasmic interactions in lymphocytes. Proc. Natl. Acad. Sci. USA 70, 1442-1446, 1973

4. GazitT, Y., I. Ohad and A. Loyter. Phosphorylation and dephosphorylation of membrane proteins as a possible mechanism for structural rearrangement of membrane components. Biochim. Biophys. Acta 436, 1-14, 1976

5. Gunther, G., J.L. Wang, I. Yahara, B. Cunningham and G.M. Edelman. Concanavalin A derivatives with altered biological activities. Proc. Natl. Acad. Sci. USA 70, 1012-1016, 1973

6. HAXDON, D.A. The surface charge of cells and some other small particles as indicated by electrophoresis. I. The zeta potential-surface charge relationships. Biochim. Biophys. Acta 50, $450-457,1961$

7. Heard, D.H. and G.V.F. Seaman. The action of lower aldehydes on the human erythrocytes. Biochim. Biophys. Acta 53, 336-374, 1961

8. INBAR, M. and L. SACHS. Interaction of the carbohydrate-binding protein concanavalin $A$ with normal and transformed cells. Proc. Natl. Acad. Sci. USA 63, 1418-1425, 1969

9. INBAR, M. and L. SACHS. Mobility of carbohydrate containing sites on the surface membrane in relation to the control of cell growth. FEBS Lett. 32, 124-128, 1973

10. Kolma, K. and A. MaEkawa. A difference in the architecture of surface membrane between 
two cell types of rat ascites hepatomas. Cancer Res. 32, 847-852, 1972

11. Martinez-Palomo, A., R. Wicker and W. Bernhard. Ultra-structural detection of concanavalin surface receptors in normal and in polyoma-transformed cells. Int. J. Cancer 9, 676684,1972

12. NiCOLSON, G.L. Difference in topology of normal and tumour cell membranes shown by different surface distributions of ferritin-conjugated concanavalin A. Nature New Biol. 233, 244 246,1971

13. Nicolson, G.L. Temperature-dependent mobility of concanavalin A sites on tumour cell surfaces. Nature New Biol. 243, 218-220, 1973

14. Ohy , T. and T. Kaneko. Novel hyaluronidase from Streptomyces. Biochim. Biophys. Acta 198, 607-609, 1970

15. Sato, C, and K. KoJma. Changes in electrophoretic mobility of cultured cells after X-irradiation and their modification by SH-blocking agents and hemagglutinin. Radiat. Res. 60, 506-515, 1974

16. Sato, C. and K. KoJima. Phytohemagglutinin-induced change in the distribution of acidic sugars in surface membrane of lymphoid cells and blocking of the radiation effect. Exp. Cell Res. 98, 90-94, 1976

17. Sato, C., K. Kojima, K. Nishizawa, S. Shimizu and M. Inoue. Small amount of concanavalin A modifies radiation-induced alteration in cell-surface depending on its binding condition. Biochim. Biophys. Acta 448, 379-387, 1976

18. Sato, $C$. and $K$. Takazawa-Nishizawa. Changes in cell-to-dish contact of cultured mammalian cells induced by concanavalin A. Exp. Cell Res. 89, 121-126, 1974

19. Silva, P.P. Translational mobility of the membrane intercalated particles of human erythrocyte ghosts. J. Cell Biol. 53. 777-787, 1972

20. SINGER, S.J. and G.L. Nicolson. The fluid mosaic model of the structure of cell membranes. Science 175, 720-731, 1972

21. Sonoda, S. and M. Schlamowitz. Studies of ${ }^{125}$ I trace labeling of immunoglobulin $G$ by chloramine-T. Immunochemistry 7, 885-898, 1970

22. YAMADA, T. and M. YAMADA. Changes in distribution of electric charges in the surface membrane of rat ascites hepatocarcinoma cells induced by Con A. Nature 244, 297-299, 1973

23. Yamagata, T., H. Saito, O. Habuchi and S. Suzuki. Purification and properties of bacterial chondroitinases and chondrosulfatases. J. Biol. Chem. 243, 1523-1535, 1968

24. Wang, J.L., G.R. Piras and G.M. Edelman. Inhibition by colchicine of the the mitogenic stimulation of lymphocytes prior to the S phase. J. Cell Biol. 66, 128-144, 1975 